\title{
Change in Fatty Acid Composition of Serum Lipids in Obese Females After Short-Term Weight-reducing Regimen with the Addition of n-3 Long Chain Polyunsaturated Fatty Acids in Comparison to Controls
}

\author{
P. HLAVATÝ ${ }^{1}$, M. KUNEŠOVÁ ${ }^{1}$, M. GOJOVÁ ${ }^{2}$, E. TVRZICKÁ ${ }^{3}$, M. VECKA ${ }^{3}$, \\ P. ROUBAL ${ }^{4}$, M. HILL ${ }^{1}$, K. HLAVATÁ ${ }^{1}$, P. KALOUSKOVÁ ${ }^{1}$, V. HAINER $^{1}$, A. $_{\text {ŻÁK }}{ }^{3}$, \\ J. DRBOHLAV ${ }^{4}$
}

${ }^{1}$ Obesity Management Centre, Institute of Endocrinology, Prague, ${ }^{2}$ Priessnitzovy léčebné lázně, Jeseník, ${ }^{3}$ Fourth Department of Internal Medicine, First Medical Faculty, Charles University, Prague, ${ }^{4}$ Milcom Prague, Prague, Czech Republic

Received November 12, 2007

Accepted January 17, 2008

On-line February 13, 2008

\begin{abstract}
Summary
Short-term weight-reducing regimens were shown to influence fatty acid composition of serum lipids unfavorably. Adding long chain $n-3$ polyunsaturated fatty acids ( $n-3$ LC PUFA) to a lowcalorie diet (LCD) could avoid these changes. The aim of this study was to examine the effect of a short-term in-patient weight-reducing regimen including LCD with yogurt enriched by low doses of n-3 PUFA ( $n-3$ LCD). The enriched yogurt contained $790 \mathrm{mg}$ of fish oil, predominantly eicosapentaenoic (20:5n-3; EPA) and docosahexaenoic (22:6n-3; DHA). Forty obese women were randomly assigned to the group consuming LCD and joghurt either with or without n-3 enrichment. Following the 3week diet in the n-3 LCD group a significantly higher increase in the proportion of n-3 LC PUFA (sum of n-3 FA, EPA and DHA) in serum lipids was confirmed. In phospholipids $(P L)$ a significant difference in the sum of $n-6$ fatty acids was found, a decrease in the n-3 LCD group and an increase in LCD group. Significantly higher increase in the PL palmitate (16:0) was shown in the LCD group. The results suggest that low doses of $n-3$ fatty acid enrichment can help to avoid unfavorable changes in fatty acid composition in serum lipids after a short-term weight-reducing regimen.
\end{abstract}

\section{Key words}

Obesity treatment - Fatty acid composition - Weight reduction • n-3 fatty acids $\bullet$ EPA $\bullet$ DHA

\section{Corresponding author}

Marie Kunešová, Institute of Endocrinology, Národní třída 8, 11694 Prague 1, Czech Republic. E-mail: mkunesova@endo.cz

\section{Introduction}

Composition of dietary fat is one of the nutritional factors, which has been shown in the last years to influence the outcome of weight-reducing regimens in human (Kriketos et al. 2001, Clifton et al. 2004, Huber et al. 2007, Krebs et al. 2006, Kunešová et al. 2006, Thorsdottir et al. 2007) as well as in animal experiments (Růžičková et al. 2004, Flachs et al. 2005). Increased beta-oxidation was shown in rodents (Ukropec et al 2003) and in human (Kunešová et al. 2006, Couet et al. 1997). Long chain fatty acids act at the preadipocyte stage during adipogenesis and stimulate the formation of adipocytes. Long chain fatty acids behave as ligands of PPAR alpha, beta/delta and gamma. Arachidonic acid $(20: 4 n-6, \quad A A)$ is the predominant precursor of eicosanoids and leucotriens participating in this process. Under isoenergetic conditions in vivo experiments have shown that diet enriched by linoleic acid (18:2n-6, LA) enhances fat mass and alpha-linolenic acid (18:3n-3, LNA), counteracting this effect. A critical role is played by AA and prostacyclin receptors in excessive adipose tissue development in the gestation/lactation period. Epidemiological studies in infants found the same results as animal experiments. So, n- 6 and n-3 fatty acids differ in their effect on development of adipose tissue (for review see Ailhaud et al. 2006). Fatty acid composition of membranes was shown to be influenced by many factors as CD36 fatty acid transporter with subsequent 
Table 1. Characteristics of obese women before treatment and the effect of the weight-reducing regimen ( $n-3$ LCD versus LCD)

\begin{tabular}{|c|c|c|c|c|c|c|c|c|c|c|c|}
\hline & \multicolumn{4}{|c|}{ LCD with n-3 } & \multicolumn{4}{|c|}{ LCD } & \multirow[b]{3}{*}{$" p$} & \multirow[b]{3}{*}{${ }^{x} p$} & \multirow[b]{3}{*}{${ }^{x x} p a$} \\
\hline & \multicolumn{2}{|c|}{ Baseline } & \multicolumn{2}{|c|}{ After 21 days } & \multicolumn{2}{|c|}{ Baseline } & \multicolumn{2}{|c|}{ After 21 days } & & & \\
\hline & Mean & $\mathrm{SD}$ & Mean & $\mathrm{SD}$ & Mean & $\mathrm{SD}$ & Mean & $\mathrm{SD}$ & & & \\
\hline Age (years) & 55.2 & 13.2 & & & 59 & 10.2 & & & NS & & \\
\hline Height (cm) & 163 & 6.98 & & & 163 & 6.74 & & & NS & & \\
\hline Weight (kg) & 87.6 & 9.5 & 85.2 & 9.54 & 96.3 & 13.9 & 92 & 13.8 & 0.03 & 0.0003 & $<0.0001$ \\
\hline$B M I$ & 33.1 & 2.83 & 32.1 & 2.9 & 36.2 & 4.11 & 34.6 & 4.14 & NS & 0.001 & $<0.0001$ \\
\hline Percentage FM & 42.2 & 4.07 & 41.6 & 3.67 & 45 & 3.9 & 41.7 & 3.9 & NS & 0.0001 & $<0.0001$ \\
\hline Fat mass ( $\mathrm{kg}$ ) & 37.2 & 6.91 & 35.6 & 5.2 & 43.5 & 9.04 & 37.1 & 2.59 & 0.02 & 0.005 & $<0.008$ \\
\hline Fat free mass (kg) & 50.4 & 4.52 & 49.6 & 4.57 & 52.9 & 5.99 & 55.7 & 3.88 & NS & NS & NS \\
\hline Waist $(\mathrm{cm})$ & 99.9 & 10.5 & 97.8 & 10.1 & 111 & 11.2 & 107 & 11 & 0.02 & NS & NS \\
\hline Hip $(\mathrm{cm})$ & 117 & 8.94 & 115 & 7.66 & 122 & 11.7 & 119 & 12.2 & NS & NS & NS \\
\hline
\end{tabular}

FM - fat mass, FFM - fat free mass, ${ }^{*} p$ significance of the difference in baseline levels between the groups, ${ }^{x} p$ significance of the difference in treatment effect between the groups, ${ }^{x x}$ pa significance of the difference in treatment effect between the groups, after adjustment for baseline weight

Table 2. Effect of the treatment on blood lipids, markers of glucose metabolism and inflammation

\begin{tabular}{|c|c|c|c|c|c|c|c|c|c|c|c|}
\hline & \multicolumn{4}{|c|}{ LCD with n-3 FA } & \multicolumn{4}{|c|}{ LCD } & \multirow[b]{3}{*}{ " p } & \multirow[b]{3}{*}{${ }^{x} p$} & \multirow[b]{3}{*}{${ }^{x x} p a$} \\
\hline & \multicolumn{2}{|c|}{$\underline{\text { Baseline }}$} & \multicolumn{2}{|c|}{$\underline{\text { After } 21 \text { days }}$} & \multicolumn{2}{|c|}{$\underline{\text { Baseline }}$} & \multicolumn{2}{|c|}{$\underline{\text { After } 21 \text { days }}$} & & & \\
\hline & Mean & SD & Mean & SD & Mean & SD & Mean & SD & & & \\
\hline$F B G(\mathrm{mmol} / \mathrm{l})$ & 5.39 & 1.24 & 4.84 & 1.42 & 5.86 & 0.9 & 5.07 & 0.65 & NS & NS & NS \\
\hline CP (nmol/l) & 1.02 & 0.29 & 1.03 & 0.26 & 1.33 & 0.42 & 1.25 & 0.38 & 0.02 & NS & NS \\
\hline Insulin (mIU/l) & 12.8 & 6.85 & 10.1 & 4.01 & 14.9 & 5.41 & 12.8 & 5.69 & NS & NS & NS \\
\hline$T C(\mathrm{mmol} / \mathrm{l})$ & 5.58 & 1.01 & 5.07 & 0.77 & 5.63 & 0.87 & 5.2 & 0.88 & NS & NS & NS \\
\hline$H D L-C(\mathrm{mmol} / \mathrm{l})$ & 1.47 & 0.4 & 1.49 & 0.32 & 1.39 & 0.33 & 1.28 & 0.3 & NS & 0.01 & 0.04 \\
\hline$L D L-C(\mathrm{mmol} / \mathrm{l})$ & 3.98 & 0.9 & 3.71 & 0.66 & 4.11 & 0.92 & 3.1 & 0.74 & NS & 0.001 & 0.001 \\
\hline$T G(\mathrm{mmol} / \mathrm{l})$ & 1.40 & 0.46 & 1.38 & 0.47 & 1.97 & 1.02 & 1.46 & 0.81 & 0.05 & 0.01 & 0.001 \\
\hline$C R P(m g / l)$ & 2.78 & 1.9 & 2.8 & 2.85 & 6.46 & 7.06 & 4.52 & 5.51 & NS & NS & NS \\
\hline
\end{tabular}

${ }^{*} p$ significance of the difference in baseline levels between the groups, ${ }^{x} p$ significance of the difference in treatment effect between the groups, ${ }^{x x}$ pa significance of the difference in treatment effect between the groups, after adjustment for baseline weight

effect on insulin sensitivity (Kontrová et al 2007). Lower proportion of $\mathrm{n}-3$ long chain polyunsaturated fatty acids (n-3 LC PUFA) in serum phospholipids content was confirmed in obese adolescents (Karlsson et al. 2006). In adults, central obesity was positively associated with high quantities of n- 6 polyunsaturated fatty acids and inversely associated with monounsaturated fatty acids and n-3 polyunsaturated fatty acids in adipose tissue (Garaulet et al. 2001).

These findings should be reflected also in changes in human dietary habits. In the Czech Republic there is low consumption of fish and fish products resulting in low n-3 long chain polyunsaturated fatty acids (n-3 LC PUFA) intake (5.8 $\mathrm{kg}$ of fish and fish products/person/year, Czech Statistical Office 2005).

Inclusion of fish oils in a weight-reducing diet has been shown to have positive effect on health risks associated with obesity (Mori et al 1999). Short-term weight-reducing regimens influence fatty acid composition of serum and adipose tissue lipids unfavorably (Phinney et al. 1990, 1991, Kunešová et al., 2002).

The aim of our study was to examine the effect of the usage of yogurt enriched with n-3 fatty acids during a weight-reducing regimen in moderately obese women. 


\section{Methods}

\section{Subjects}

Forty moderately obese women were randomly assigned to a low calorie diet including yogurt containing n-3 PUFA supplement ( $\mathrm{n}-3$ LCD, n=20) or yogurt without $n-3$ supplementation (LCD, $n=20)$ during their weight-reducing regimen in the Spa Obesity Unit in spring 2004. Characteristics of the study subjects at the baseline are given in Tables 1 and 2 . The women were mostly postmenopausal and the number of premenopausal women was similar in both groups. Subjects with diabetes, uncompensated thyroid dysfunction and subjects treated with hormonal contraceptives or hormonal replacement therapy, diuretics or other drugs affecting water balance were excluded from the study.

The study was approved by the Medical Ethical Committee of the Institute of Endocrinology.

\section{Design of the study}

The weight-reducing regimen consisted of a baseline weight stabilization period followed by an inpatient weight-reducing period. The regimen included a defined low calorie diet (LCD), daily light to moderate physical activity supervised by a physiatrist and cognitive behavioral modification of lifestyle. The diet was prepared in the spa central kitchen and its energy content was calculated using the PC program „Nutrition“. This software has nearly 3000 food items, and its evaluation includes energy intake, macronutrient and micronutrient content. Patients consumed a weight maintenance diet during their initial 3 days of the in-patient stay. Then the LCD was started with $5500 \mathrm{~kJ} /$ day (protein $22.7 \%$, fat $28.7 \%$, carbohydrate $48.6 \%$ ). The energy deficit was $2500 \mathrm{~kJ} /$ day compared to both the calculated energy expenditure and the diet during the weight maintenance period. The patients were assigned to LCD either including yogurt supplemented with n-3 highly unsaturated fatty acids (n-3 LCD) or without this supplement (LCD). Supplemented yogurt contained 790 $\mathrm{mg} /$ day of n-3 PUFA, from which, $620 \mathrm{mg}$ /day was eicosapentaenoic (EPA, 20:5n-3) and docosahexaenoic (DHA, 20:6 n-3) acid. The yogurt was produced by Dairy Research Institute Milcom ${ }^{\circledR}$. The weight-reducing regimen included daily light to moderate physical activity lasting about $60 \mathrm{~min} /$ day.

Body composition, laboratory analysis and psychobehavioral examination were investigated before the intervention and after 21 days of weight-reducing regimen.

\section{Biochemical analysis}

Blood samples were drawn in the morning after 12 hour overnight fasting. Biochemical parameters measured included total cholesterol (TC), HDLcholesterol (HDL-C), LDL cholesterol (LDL-C), triglycerides (TG), fasting blood glucose (FBG), fasting serum insulin (insulin), C-peptide (CP) and C-reactive protein (CRP). Laboratory analyses were performed by routine laboratory methods.

\section{Fatty acid composition}

The measurement of fatty acid composition of serum lipids was performed by gas chromatography after separation of individual serum lipid fractions (serum phospholipids - PL, triglycerides - TG and cholesterol esters - CE) by thin-layer chromatography on silica gel (Tvrzická et al. 2002).

\section{Body composition and regional tissue distribution}

Anthropometric estimation of body fat was performed by measurement of the following skinfolds: subscapular, suprailiac, triceps and biceps. Waist and hip circumference were measured following the standardized procedure recommended at the Airlie Conference (Lohman et al. 1989). Body fat content was estimated by bioelectrical impedance measurement (Tanita BC 418 MA, Tanita Inc., Japan).

\section{Psychobehavioral examination}

Eating behavior was evaluated by the 3 -item Eating Inventory (Stunkard and Messick 1985) and for the evaluation of depression score the Beck Depression Inventory (Beck et al. 1961) was used.

\section{Statistical methods}

Data are expressed as means \pm SD. The MannWhitney robust test was used for testing the differences between groups, while the Wilcoxon test was applied for evaluation of treatment effect. The differences between individual groups or subgroups were evaluated using ANOVA and least significant difference multiple comparisons.

\section{Results}

The characteristics of the group and the results 
Table 3a. Fatty acid composition in serum lipids before and after treatment - Phospholipids

\begin{tabular}{|c|c|c|c|c|}
\hline \multirow{2}{*}{$\begin{array}{l}\text { Phospholipids } \\
\text { Fatty acid }\end{array}$} & \multicolumn{2}{|c|}{$\begin{array}{c}\text { LCD with n-3 FA } \\
n=20\end{array}$} & \multicolumn{2}{|c|}{$\begin{array}{l}\text { LCD } \\
n=19\end{array}$} \\
\hline & Baseline & Day 21 & Baseline & Day 21 \\
\hline $12: 0$ & $0.05 \pm 0.05$ & $0.05 \pm 0.03$ & $0.03 \pm 0.01$ & $0.03 \pm 0.01$ \\
\hline 14:0 & $0.60 \pm 0.72$ & $0.53 \pm 0.57$ & $0.22 \pm 0.06$ & $0.18 \pm 0.04 * * *$ \\
\hline $14: 1 n-5$ & $0.03 \pm 0.05$ & $0.03 \pm 0.04$ & $0.01 \pm 0.01$ & $0.01 \pm 0.00$ \\
\hline $16: 0$ & $29.97 \pm 1.60$ & $29.59 \pm 1.93$ & $29.95 \pm 1.08$ & $31.14 \pm 1.12 * * *++$ \\
\hline $16: 1 n-9$ & $0.17 \pm 0.16$ & $0.19 \pm 0.19$ & $0.09 \pm 0.01$ & $0.09 \pm 0.01$ \\
\hline $16: 1 n-7 c$ & $1.12 \pm 1.14$ & $1.18 \pm 1.26$ & $0.51 \pm 0.11$ & $0.49 \pm 0.09$ \\
\hline $18: 0$ & $11.44 \pm 4.44$ & $11.15 \pm 4.47^{*}$ & $14.14 \pm 1.15$ & $12.59 \pm 1.15^{* * *+++}$ \\
\hline $18: 1 n-9$ & $15.28 \pm 12.30$ & $14.69 \pm 12.16$ & $9.05 \pm 0.69$ & $9.05 \pm 0.73$ \\
\hline $18: 1 n-7$ & $1.70 \pm 0.48$ & $1.77 \pm 0.51$ & $1.46 \pm 0.18$ & $1.61 \pm 0.17 * * *$ \\
\hline $18: 2 n-6$ & $21.68 \pm 4.85$ & $21.08 \pm 3.60$ & $21.89 \pm 3.12$ & $22.39 \pm 3.08+$ \\
\hline $18: 3 n-6$ & $0.10 \pm 0.08$ & $0.11 \pm 0.12$ & $0.07 \pm 0.03$ & $0.06 \pm 0.03$ \\
\hline $18: 3 n-3$ & $0.29 \pm 0.26$ & $0.28 \pm 0.27$ & $0.16 \pm 0.06$ & $0.14 \pm 0.04$ \\
\hline $20: 0$ & $0.03 \pm 0.01$ & $0.03 \pm 0.01$ & $0.03 \pm 0.00$ & $0.03 \pm 0.00^{*}$ \\
\hline $20: 1 n-9$ & $0.14 \pm 0.04$ & $0.13 \pm 0.03^{*}$ & $0.12 \pm 0.02$ & $0.12 \pm 0.01+$ \\
\hline $20: 2 n-6$ & $0.42 \pm 0.11$ & $0.37 \pm 0.08 * * *$ & $0.44 \pm 0.12$ & $0.37 \pm 0.06^{* * *}$ \\
\hline $20: 3 n-6$ & $2.66 \pm 1.33$ & $2.47 \pm 1.23 *$ & $3.19 \pm 0.67$ & $2.75 \pm 0.70 * *$ \\
\hline $20: 4 n-6$ & $9.17 \pm 4.56$ & $9.46 \pm 4.57$ & $12.18 \pm 1.63$ & $12.81 \pm 1.92 *$ \\
\hline $20: 5 n-3$ & $0.79 \pm 0.55$ & $1.44 \pm 0.66^{* * *}$ & $1.17 \pm 0.46$ & $0.78 \pm 0.22 * *+++$ \\
\hline $22: 4 n-6$ & $0.25 \pm 0.08$ & $0.23 \pm 0.06^{* *}$ & $0.26 \pm 0.05$ & $0.26 \pm 0.04$ \\
\hline $22: 5 n-6$ & $0.18 \pm 0.08$ & $0.16 \pm 0.06^{*}$ & $0.16 \pm 0.05$ & $0.16 \pm 0.05+$ \\
\hline $22: 5 n-3$ & $0.66 \pm 0.22$ & $0.79 \pm 0.24 * * *$ & $0.78 \pm 0.14$ & $0.76 \pm 0.14+++$ \\
\hline $22: 6 n-3$ & $3.24 \pm 1.71$ & $4.25 \pm 1.87 * * *$ & $4.10 \pm 0.81$ & $4.17 \pm 0.82+++$ \\
\hline Saturated & $42.10 \pm 3.99$ & $41.35 \pm 5.17$ & $44.37 \pm 0.84$ & $43.97 \pm 0.95^{*}$ \\
\hline Monounsaturated & $18.46 \pm 14.07$ & $18.00 \pm 14.06$ & $11.23 \pm 0.78$ & $11.37 \pm 0.78$ \\
\hline PUFA n-6 & $34.46 \pm 8.96$ & $33.89 \pm 7.16$ & $38.19 \pm 1.62$ & $38.81 \pm 1.92+++$ \\
\hline PUFA n-3 & $4.98 \pm 2.10$ & $6.76 \pm 2.43 * * *$ & $6.21 \pm 1.17$ & $5.85 \pm 1.01+++$ \\
\hline
\end{tabular}

Values are expressed as mean \pm S.E.M. (in mol \%), $* p<0.05 * * p<0.01 * * * p<0.001$ in comparison with baseline value, $+p<0.05$ $++p<0.01+++p<0.001$ in comparison with change in the LCD group

of the weight-reducing regimen are shown in Table 1. Significantly higher initial weight, fat mass and waist circumference was found in the control group which was the most likely cause of the higher weight, BMI, per cent of fat and fat mass loss in the LCD group after the weight-reducing regimen.

In n-3 LCD an increase in HDL-cholesterol was found, while the LCD group showed a decrease, nevertheless, in LDL cholesterol a significantly higher decrease was found in the LCD group. Basal triglycerides (TG) were significantly higher and their decrease was higher after weight reduction in the LCD group (see Table 2). Differences in the changes in glucose metabolism were not found (fasting glucose, fasting insulin and C-peptide). Changes in characteristics of food intake and Beck depression score were not significantly different (data not shown).

In all examined lipids fractions the increase in $n$ 3 fatty acids in the treated group in comparison with controls was found (Table 3a-c). The increase in n-3 fatty acid proportion in the n-3 LCD group was accompanied by a significant decrease of n- 6 fatty acid proportion in serum phospholipids (PL) in comparison with LCD group. On the contrary, a significant increase in proportion of arachidonic acid (20:4n-6) and palmitic acid (16:0) in the LCD group PL was shown. Stearic acid (18:0) in PL decreased in both groups, the decline was significantly higher in LCD group. The changes in fatty 
Table 3b. Fatty acid composition in serum lipids before and after treatment - Triglycerides

\begin{tabular}{|c|c|c|c|c|}
\hline \multirow{2}{*}{$\begin{array}{l}\text { Triglycerides } \\
\text { Fatty acid }\end{array}$} & \multicolumn{2}{|c|}{$\begin{array}{l}\text { LCD with n-3 FA } \\
n=20\end{array}$} & \multicolumn{2}{|c|}{$\begin{array}{l}\text { LCD } \\
n=19\end{array}$} \\
\hline & Baseline & Day 21 & Baseline & Day 21 \\
\hline $12: 0$ & $0.17 \pm 0.10$ & $0.13 \pm 0.09 *$ & $0.18 \pm 0.15$ & $0.12 \pm 0.04 *$ \\
\hline $14: 0$ & $1.76 \pm 0.53$ & $1.66 \pm 0.52$ & $1.63 \pm 0.44$ & $1.29 \pm 0.25 * * *+$ \\
\hline $14: 1 n-5$ & $0.11 \pm 0.07$ & $0.10 \pm 0.04$ & $0.09 \pm 0.04$ & $0.07 \pm 0.02 *$ \\
\hline $16: 0$ & $28.29 \pm 2.71$ & $27.38 \pm 3.32 *$ & $27.74 \pm 2.06$ & $27.46 \pm 1.19$ \\
\hline $16: 1 n-9$ & $0.60 \pm 0.10$ & $0.65 \pm 0.13^{* *}$ & $0.64 \pm 0.10$ & $0.60 \pm 0.11++$ \\
\hline $16: 1 n-7 c$ & $3.84 \pm 0.92$ & $4.06 \pm 0.96$ & $3.73 \pm 0.87$ & $3.53 \pm 0.72+$ \\
\hline 18:0 & $3.10 \pm 0.53$ & $2.86 \pm 0.74^{*}$ & $3.01 \pm 0.55$ & $2.71 \pm 0.44^{* *}$ \\
\hline $18: 1 n-9$ & $39.21 \pm 2.63$ & $38.10 \pm 3.48$ & $40.31 \pm 2.72$ & $40.79 \pm 2.06$ \\
\hline $18: 1 n-7$ & $2.75 \pm 0.36$ & $2.72 \pm 0.36$ & $2.73 \pm 0.31$ & $2.76 \pm 0.25$ \\
\hline $18: 2 n-6$ & $15.87 \pm 2.73$ & $17.24 \pm 3.75^{* *}$ & $15.66 \pm 2.13$ & $16.62 \pm 2.69^{*}$ \\
\hline $18: 3 n-6$ & $0.26 \pm 0.11$ & $0.31 \pm 0.17$ & $0.25 \pm 0.11$ & $0.25 \pm 0.07$ \\
\hline $18: 3 n-3$ & $0.74 \pm 0.25$ & $0.84 \pm 0.27^{*}$ & $0.85 \pm 0.25$ & $0.81 \pm 0.24$ \\
\hline $20: 0$ & $0.03 \pm 0.01$ & $0.03 \pm 0.01$ & $0.03 \pm 0.01$ & $0.03 \pm 0.01$ \\
\hline $20: 1 n-9$ & $0.21 \pm 0.04$ & $0.19 \pm 0.03 *$ & $0.22 \pm 0.04$ & $0.20 \pm 0.02 *$ \\
\hline $20: 2 n-6$ & $0.23 \pm 0.04$ & $0.21 \pm 0.06$ & $0.21 \pm 0.05$ & $0.20 \pm 0.06$ \\
\hline $20: 3 n-6$ & $0.27 \pm 0.05$ & $0.26 \pm 0.07$ & $0.23 \pm 0.04$ & $0.21 \pm 0.03 *$ \\
\hline $20: 4 n-6$ & $1.25 \pm 0.26$ & $1.26 \pm 0.24$ & $1.22 \pm 0.34$ & $1.20 \pm 0.20$ \\
\hline $20: 5 n-3$ & $0.16 \pm 0.12$ & $0.29 \pm 0.10 * *$ & $0.18 \pm 0.09$ & $0.13 \pm 0.04 *+++$ \\
\hline $22: 4 n-6$ & $0.14 \pm 0.03$ & $0.14 \pm 0.03$ & $0.13 \pm 0.03$ & $0.13 \pm 0.02$ \\
\hline $22: 5 n-6$ & $0.09 \pm 0.02$ & $0.09 \pm 0.02$ & $0.08 \pm 0.02$ & $0.08 \pm 0.01$ \\
\hline $22: 5 n-3$ & $0.28 \pm 0.10$ & $0.39 \pm 0.09 * *$ & $0.27 \pm 0.07$ & $0.27 \pm 0.07+++$ \\
\hline $22: 6 n-3$ & $0.63 \pm 0.36$ & $1.08 \pm 0.41 * *$ & $0.62 \pm 0.25$ & $0.55 \pm 0.23+++$ \\
\hline Saturated & $33.36 \pm 3.33$ & $32.05 \pm 4.16^{*}$ & $32.58 \pm 2.48$ & $31.62 \pm 1.42 *$ \\
\hline Monounsaturated & $46.73 \pm 2.88$ & $45.83 \pm 4.10$ & $47.71 \pm 2.57$ & $47.94 \pm 2.50$ \\
\hline PUFA n-6 & $18.10 \pm 2.91$ & $19.51 \pm 3.90^{* *}$ & $17.78 \pm 2.13$ & $18.68 \pm 2.62 *$ \\
\hline PUFA n-3 & $1.81 \pm 0.70$ & $2.60 \pm 0.77 * *$ & $1.92 \pm 0.55$ & $1.75 \pm 0.48+++$ \\
\hline
\end{tabular}

Values are expressed as mean \pm SE (in mol \%), *p<0.05**p<0.01***p<0.001 in comparison with baseline value, $+p<0.05$ $++p<0.01+++p<0.001$ in comparison with change in the LCD group

acid composition were found in phospholipids in the highest rate, while the changes in fatty acid composition in serum triglycerides and cholesteryl esters were not so striking, and the least change was found in cholesteryl esters.

\section{Discussion}

The higher initial weight, BMI and body fat lead to significantly higher weight, BMI and body fat loss in the control group following the 3 week in-patient weightreducing regimen as shown previously (Hainer et al. 2005, Packianathan et al. 2005). On the other hand, we found significant changes in fatty acid composition of serum lipids after the calorie restricted diet containing yogurt supplemented with low doses of n-3 fatty acids of fish origin (n-3LCD). A significant increase in EPA (20:5n-3), DHA (22:6n-3) and the sum of n-3 fatty acids in the n-3 LCD group in contrast with the control group consuming LCD with yogurt without supplementation was confirmed.

The increase in HDL cholesterol caused by the consumption of fish oil was noted by Barret and Watts (2003). We confirmed the positive effect of $n-3$ supplementation on HDL-C in our study. We did not find a hypotriglyceridaemic effect of fish oil supplementation (Marsh et al. 1987, Sanders et al. 2006, Surette et al. 1992) probably as a result of a significantly higher initial 
Table 3c. Fatty acid composition in serum lipids before and after treatment - Cholesterol esters

\begin{tabular}{|c|c|c|c|c|}
\hline \multirow{2}{*}{$\begin{array}{l}\text { Cholesterol esters } \\
\text { Fatty acid }\end{array}$} & \multicolumn{2}{|c|}{$\begin{array}{l}\text { LCD with n-3 FA } \\
n=20\end{array}$} & \multicolumn{2}{|c|}{$\begin{array}{l}\text { LCD } \\
n=19\end{array}$} \\
\hline & Baseline & Day 21 & Baseline & Day 21 \\
\hline $12: 0$ & $0.11 \pm 0.05$ & $0.11 \pm 0.07$ & $0.13 \pm 0.07$ & $0.13 \pm 0.06$ \\
\hline 14:0 & $0.77 \pm 0.22$ & $0.71 \pm 0.18$ & $0.61 \pm 0.17$ & $0.47 \pm 0.12 * * *$ \\
\hline $14: 1 n-5$ & $0.06 \pm 0.04$ & $0.05 \pm 0.02$ & $0.06 \pm 0.04$ & $0.06 \pm 0.05$ \\
\hline $16: 0$ & $10.93 \pm 0.84$ & $10.74 \pm 0.89$ & $10.70 \pm 0.89$ & $10.36 \pm 1.29$ \\
\hline $16: 1 n-9$ & $0.42 \pm 0.09$ & $0.38 \pm 0.07 * *$ & $0.40 \pm 0.10$ & $0.36 \pm 0.06^{*}$ \\
\hline $16: 1 n-7 c$ & $3.36 \pm 1.00$ & $3.26 \pm 0.81$ & $3.15 \pm 0.89$ & $2.87 \pm 0.73 *$ \\
\hline $18: 0$ & $0.56 \pm 0.10$ & $0.50 \pm 0.11^{*}$ & $0.55 \pm 0.08$ & $0.47 \pm 0.10 * *$ \\
\hline $18: 1 n-9$ & $17.67 \pm 1.78$ & $17.21 \pm 1.69$ & $17.53 \pm 1.42$ & $17.06 \pm 1.80$ \\
\hline $18: 1 n-7$ & $1.04 \pm 0.12$ & $1.10 \pm 0.19^{*}$ & $1.03 \pm 0.13$ & $1.11 \pm 0.16^{* *}$ \\
\hline $18: 2 n-6$ & $55.89 \pm 5.62$ & $55.45 \pm 5.48$ & $55.36 \pm 4.72$ & $55.51 \pm 4.22$ \\
\hline $18: 3 n-6$ & $0.76 \pm 0.40$ & $0.77 \pm 0.37$ & $0.88 \pm 0.50$ & $0.73 \pm 0.32 * *$ \\
\hline $18: 3 n-3$ & $0.51 \pm 0.10$ & $0.50 \pm 0.09$ & $0.47 \pm 0.14$ & $0.44 \pm 0.09$ \\
\hline $20: 0$ & $0.01 \pm 0.01$ & $0.01 \pm 0.01$ & $0.01 \pm 0.01$ & $0.01 \pm 0.01$ \\
\hline $20: 1 n-9$ & $0.04 \pm 0.02$ & $0.04 \pm 0.02$ & $0.04 \pm 0.02$ & $0.04 \pm 0.02$ \\
\hline $20: 2 n-6$ & $0.06 \pm 0.02$ & $0.06 \pm 0.04$ & $0.07 \pm 0.02$ & $0.06 \pm 0.02$ \\
\hline $20: 3 n-6$ & $0.68 \pm 0.14$ & $0.64 \pm 0.13^{*}$ & $0.69 \pm 0.12$ & $0.63 \pm 0.14 * *$ \\
\hline $20: 4 n-6$ & $6.36 \pm 2.43$ & $7.24 \pm 2.07 *$ & $7.31 \pm 2.33$ & $8.67 \pm 2.53 * *$ \\
\hline $20: 5 n-3$ & $0.42 \pm 0.44$ & $0.73 \pm 0.46^{* *}$ & $0.56 \pm 0.47$ & $0.49 \pm 0.31+++$ \\
\hline $22: 4 n-6$ & $0.02 \pm 0.01$ & $0.03 \pm 0.04$ & $0.02 \pm 0.01$ & $0.02 \pm 0.01$ \\
\hline $22: 5 n-6$ & $0.02 \pm 0.01$ & $0.01 \pm 0.01$ & $0.02 \pm 0.01$ & $0.02 \pm 0.01$ \\
\hline $22: 5 n-3$ & $0.03 \pm 0.02$ & $0.04 \pm 0.01$ & $0.04 \pm 0.01$ & $0.05 \pm 0.04$ \\
\hline $22: 6 n-3$ & $0.29 \pm 0.21$ & $0.42 \pm 0.23 * *$ & $0.35 \pm 0.24$ & $0.44 \pm 0.20 *$ \\
\hline Saturated & $12.37 \pm 0.98$ & $12.08 \pm 1.04$ & $12.00 \pm 1.00$ & $11.44 \pm 1.35^{* *}$ \\
\hline Monounsaturated & $22.59 \pm 2.61$ & $22.03 \pm 2.46$ & $22.23 \pm 2.22$ & $21.50 \pm 2.41$ \\
\hline PUFA n-6 & $63.79 \pm 3.77$ & $64.20 \pm 3.59$ & $64.35 \pm 3.08$ & $65.64 \pm 3.39^{*}$ \\
\hline PUFA $n-3$ & $1.25 \pm 0.68$ & $1.69 \pm 0.70 * *$ & $1.42 \pm 0.76$ & $1.42 \pm 0.54++$ \\
\hline
\end{tabular}

Values are expressed as mean \pm S.E.M. (in mol \%), $* p<0.05, * * p<0.01, * * * p<0.001$ in comparison with baseline value, $+p<0.05$, $++p<0.01,+++p<0.001$ in comparison with change in the LCD group

triglyceride level in the control group and due to higher effect of low calorie diet and higher weight loss on triglyceride level in comparison with the effect of low dose of n-3 fatty acids. The recommended dose for treatment of hypertriglyceridaemia is approximately 2-4g/day (McKenney and Sicca 2007), a much higher dose than the one used in the study. The greater decrease of LDL-C in the control group can be caused by similar reasons and concurrently is in accordance with others (Szapary and Rader 2001).

In the Japanese population and in the Inuit of Greenland high consumption of fish and fish products results in low ratios of n- 6 AA to n-3 EPA with the Japanese showing AA/EPA ratios of approximately 1.7 and the Greenland Inuit showing ratios of less than 1.0 (Hirai et al. 1980). Young et al. (2005) gave high dose of oils 60g/day; fish oil (39 g EPA and DHA), flax oil (36g alpha-linolenic acid 18:3n-3) and olive oil (less than $0.6 \mathrm{~g}$ of n-3 fatty acids) to subjects with attention deficit/hyperactivity disorder. They found a significant effect on serum phospholipid fatty acid composition with a significant increase of $\mathrm{n}-3$ fatty acid proportion reflecting oil composition. A significant decrease in the AA/EPA ratio in the fish oil supplemented group was shown. Unfavorable changes have been shown in fatty acid composition of serum lipids after short-term weight loss (Phinney et al. 1990, 1991, Kunešová et al., 2002). In our study we found that adding a low dose of long 
chain fish oil supplement to a typical foodstuff such as yogurt increased the proportion of EPA and DHA in serum lipids (phospholipids, triglycerides, cholesteryl esters) during a low calorie diet in obese women. The AA/EPA ratio in phospholipids decreased from 11.6 to 6.5 in the treated subjects and increased from 10.4 to 16.4 in controls.

The role of the use of novel foods enriched with n-3 LC PUFA was confirmed in a study which showed an increase in the proportion of EPA and DHA in plasma and also mononuclear and platelet phospholipids as a result of consuming foodstuffs naturally containing n-3 PUFA and items fortified with fish oil (margarine spread, milk, sausages etc.) in healthy males (Metcalf et al. 2003). The changes in fatty acid composition were greatest in phospholipids while the changes in fatty acid composition in serum triglycerides and cholesteryl esters were less pronounced. Our results confirm that plasma phospholipids are sensitive markers of the fatty acid composition of food and they also reflect the fatty acid composition of membranes. In contrast, cholesteryl esters reflect longer-term intake (Zock et al. 1997).

In conclusion the results of the study show that low dose supplementation of $n-3$ polyunsaturated fatty acids in yogurt in a low calorie diet increase the proportion of n-3 PUFA in serum lipids and prevent unfavorable changes in serum fatty acid composition following a short term low calorie diet.

\section{Conflict of Interest}

There is no conflict of interest.

\section{Acknowledgements}

The study was supported by grant NR/7782-4 from IGA of the Ministry of Health of the Czech Republic.

\section{References}

AILHAUD G, MASSIERA F, WEILL P, LEGRAND P, ALESSANDRI JM, GUESNET P: Temporal changes in dietary fats: role of $n-6$ polyunsaturated fatty acids in excessive adipose tissue development and relationship to obesity. Prog Lipid Res 45: 203-236, 2006.

BARRETT PHR, WATTS GF: Kinetic studies on lipoprotein metabolism in the metabolic syndrome including the effects of nutritional interventions. Curr Opin Lipidol 14: 61-68, 2003.

BECK AT, WARD CH, MENDELSON M, MOCK J, ERBGAUGH J. An inventory for measuring depression. Arch Gen Psychiatry 4: 561-571, 1961.

CLIFTON PM, NOAKES M, KEOGH JB: Very low-fat (12\%) and high monounsaturated fat (35\%) diets do not differentially affect abdominal fat loss in overweight, nondiabetic women. J Nutr 134: 1741-1745, 2004.

COUET C, DELARUE J, RITZ P, ANTOINE JM, LAMISSE F: Effect of dietary fish oil on body fat mass and basal fat oxidation in healthy adults. Int J Obes 21: 637-643, 1997.

CZECH STATISTICAL OFFICE: http://www.czso.cz/csu/2006edicniplan.nsf/engt/34004EF06E/\$File/3004rr_01.xls

FLACHS P, HORÁKOVÁ O, BRAUNER P, ROSSMEISL M, PECINA P, FRANSSEN-VAN HAL N, RŮŽIČKOVÁ J, ŠPONAROVÁ J, DRAHOTA Z, VLČEK C, KEIJER J, HOUŠTĚK J, KOPECKÝ J: Polyunsaturated fatty acids of marine origin upregulate mitochondrial biogenesis and induce beta-oxidation in white fat. Diabetologia 48: 2365-2375, 2005.

GARAULET M, PÉREZ-LLAMAS F, PÉREZ-AYALA M, MARTÍNEZ P, SÁNCHEZ DE MEDINA F, TEBAR FJ, ZAMORA S: Site-specific differences in the fatty acid composition of abdominal adipose tissue in an obese population from a Mediterranean area: relation with dietary fatty acids, plasma lipid profile, serum insulin, and central obesity. Amer J Clin Nutr 74: 585-591, 2001.

HAINER V, KUNEŠOVÁ M, BELLISLE F, HILL M, BRAUNEROVÁ R, WAGENKNECHT M: Psychobehavioral and nutritional predictors of weight loss in obese women treated with sibutramine. Int J Obes 29: 208-216, 2005.

HIRAI A, HAMAZAKI T, TERANO T, NISHIKAWA T, TAMURA Y, SAJIKI J: Eicosapentaenoic acid and platelet function in Japanese (letter). Lancet 2: 1132-1133, 1980.

HUBER J, LOFFLER M, BILBAN M, REIMERS M, KADL A, TODORIC J, ZEYDA M, GEYEREGGER R, SCHREIER M, WEICHHART T, LEITINGER N, WALDHAUSL W, STULNIG TM: Prevention of high-fat diet-induced adipose tissue remodeling in obese diabetic mice by n-3 polyunsaturated fatty acids. Int $J$ Obes Relat Metab Disord 31: 1004-1013, 2007. 
KARLSSON M, MÅRILD S, BRANDBERG J, LÖNN L, FRIBERG P, STRANDVIK B: Serum phospholipid fatty acids, adipose tissue, and metabolic markers in obese adolescents. Obesity 14: 1931-1939, 2006.

KONTROVÁ K, ZÍDKOVÁ J, BARTOŠ B, SKOP V, SAJDOK J, KAZDOVÁ L, MIKULÍK K, MLEJNEK P, ZÍDEK V, PRAVENEC M: CD36 regulates fatty acid composition and sensitivity to insulin in 3T3-L1 adipocytes. Physiol. Res. 56: 493-496, 2007.

KREBS JD, BROWNING LM, MCLEAN NK, ROTHWELL JL, MISHRA GD, MOORE CS, JEBB SA: Additive benefits of long-chain n-3 polyunsaturated fatty acids and weight-loss in the management of cardiovascular disease risk in overweight hyperinsulinaemic women. Int J Obes Relat Metab Disord 30: 1535-1544, 2006.

KRIKETOS AD, ROBERTSON RM, SHARP TA, DROUGAS H, REED GW, STORLIEN LH, HILL JO: Role of weight loss and polyunsaturated fatty acids in improving metabolic fitness in moderately obese, moderately hypertensive subjects. J Hypertens 19: 1745-54, 2001.

KUNEŠOVÁ M, PHINNEY S, HAINER V, TVRZICKÁ E, ŠTICH V, PǍ̌ÍZKOVÁ J, ŽÁK A, STUNKARD A: The responses of serum and adipose fatty acids to a one-year weight reduction regimen in female obese monozygotic twins. Ann N Y Acad Sci 967: 311-323, 2002.

KUNEŠOVÁ M, BRAUNEROVÁ R, HLAVATÝ P, TVRZICKÁ E, STAŇKOVÁ B, ŠKRHA J, HILGERTOVÁ J, HILL M, KOPECKÝ J, WAGENKNECHT M, HAINER V, MATOULEK M, PAŘÍZKOVÁ J, ŽÁK A, SVAČINA S: The influence of $\mathrm{n}-3$ polyunsaturated fatty acids and very low calorie diet during a short-term weight-reducing regimen on weight loss and serum fatty acid composition in severely obese women. Physiol Res 55: 63-72, 2006.

LOHMAN T, ROCHE A, MARTOREL R: (eds.) Standardization of Anthropometric Measurements. Human Kinetics Publishers, Champaign, IL. 1989.

MARSH JB, TOPPING DL, NESTEL PJ. Comparative effects of dietary fish oil and carbohydrate on plasma lipids and hepatic activities of phosphatidate phosphohydrolase, diacylglycerol acyltransferase and neutral lipase activities in the rat. Biochim Biophys Acta 922: 239-243, 1987.

MCKENNEY JM, SICA D: Role of prescription omega-3 fatty acids in the treatment of hypertriglyceridemia. Pharmacotherapy 27: 715-728, 2007.

METCALF RG, JAMES MJ, MANTZIORIS E, CLELAND LG: A practical approach to increasing intakes of n-3 polyunsaturated fatty acids: use of novel foods enriched with n-3 fats. Eur J Clin Nutr 57: 1605-1612, 2003.

MORI TA, BAO DQ, BURKE V, PUDDEY IB, WATTS GF, BEILIN LJ: Dietary fish as a major component of a weight-loss diet: effect on serum lipids, glucose, and insulin metabolism in overweight hypertensive subjects. Am J Clin Nutr 70: 817-825, 1999.

PACKIANATHAN I, SHEIKH M, BONIFACE D, FINER N: Predictors of program adherence and weight loss in women in an obesity program using meal replacements. Diabetes Obes Metab 7: 439-447, 2005.

PHINNEY SD, TANG AB, JOHNSON SB, HOLMAN RT: Reduced adipose 18:3w3 with weight loss by very low calorie dieting. Lipids 25: 798-806, 1990.

PHINNEY SD, DAVIS PG, JOHNSON SB, HOLMAN RT: Obesity and weight loss alter serum polyunsaturated lipids in humans. Am J Clin Nutr 53: 831-838, 1991.

RŮŽIČKOVÁ J, ROSSMEISL M, PRAŽÁK T, FLACHS P, ŠPONAROVÁ J, BRYHN M, KOPECKÝ J: Omega-3 polyunsaturated fatty acids of marine origin reduce dietary obesity in mice by affecting cellularity of adipose tissue. Lipids 39: 1177-1185, 2004.

SANDERS TAB, LEWIS F, SLAUGHTER S, GRIFFIN BA, GRIFFIN M, DAVIES I, MILLWARD DJ, COOPER JA, MILLER GJ: Effect of varying the ratio of n- 6 to $n-3$ fatty acids by increasing the dietary intake of $\alpha$-linolenic acid, eicosapentaenoic and docosahexaenoic acid, or both on fibrinogen and clotting factors VII and XII in persons aged 45-70 y: the OPTILIP Study Am J Clin Nutr 84: 513-522, 2006.

STUNKARD AJ, MESSICK S: The three-factor eating questionnaire to measure dietary restraint, disinhibition and hunger. J Psychosom Res 29: 71-83, 1985.

SURETTE ME, WHELAN J, BROUGHTON KS, KINSELLA JE: Evidence for the mechanisms of the hypotriglyceridemic effect of n-3 polyunsaturated fatty acids. Biochim Biophys Acta 1126: 199-205, 1992. 
SZAPARY PO, RADER DJ. Pharmacological management of high triglycerides and low high density lipoprotein cholesterol. Curr Opin Pharmacol 1: 113-120, 2001.

THORSDOTTIR I, TOMASSON H, GUNNARSDOTTIR I, GISLADOTTIR E, KIELY M, PARRA MD, BANDARRA NM, SCHAAFSMA G, MARTINÉZ JA: Randomized trial of weight-loss-diets for young adults varying in fish and fish oil content. Int J Obes 31: 1560-1566, 2007.

TVRZICKÁ E, VECKA M, STAŇKOVÁ B, ŽÁK A: Analysis of fatty acids in plasma lipoproteins by gas chromatography-flame ionization detection. Quantitative aspects. Anal Chim Acta 465: 337-350, 2002.

UKROPEC J, RESELAND JE, GAŠPERIKOVÁ D, DEMČÁKOVÁ E, MADSEN L, BERGE RK, RUSTAN AC, KLIMEŠ I, DREVON CA, ŠEBÖKOVÁ E: The hypotriglyceridemic effect of dietary n-3 FA is associated with increased beta-oxidation and reduced leptin expression. Lipids 38: 1023-1029, 2003.

YOUNG GS, CONQUER JA, THOMAS R: Effect of randomized supplementation with high dose olive, flax or fish oil on serum phospholipid fatty acid levels in adults with attention deficit hyperactivity disorder. Reprod Nutr Dev 45: 549-558, 2005.

ZOCK PL, MENSINK RP, HARRYVAN J, DE VRIES JH, KATAN MB: Fatty acids in serum cholesteryl esters as quantitative biomarkers of dietary intake in humans Am J Epidemiol 145: 1114-1122, 1997. 